\title{
Unconventional vortex dynamics in superconducting states with broken time reversal symmetry
}

\section{Doctoral Thesis}

Author(s):

Dumont, Elisabeth M.M.

Publication date:

2000

Permanent link:

https://doi.org/10.3929/ethz-a-004085269

Rights / license:

In Copyright - Non-Commercial Use Permitted 


\title{
Unconventional Vortex Dynamics in Superconducting States with Broken Time Reversal Symmetry
}

\author{
A dissertation submitted to the \\ SWISS FEDERAL INSTITUTE OF TECHNOLOGY \\ ZURICH \\ for the degree of \\ Doctor of Natural Sciences \\ presented by \\ ELISABETH M. M. DUMONT \\ Dipl. Phys. ETH \\ born on the $2^{\text {nd }}$ April 1973 \\ citizen of Luxembourg
}

accepted on the recommendation of

Prof. Dr. A. C. Mota, examiner

Prof. Dr. T. M. Rice, comexaminer

Prof. Dr. M. Sigrist, co-examiner 


\section{Abstract}

In this thesis, we report investigations of vortex dynamics in the unconventional superconductors $\mathrm{Sr}_{2} \mathrm{RuO}_{4}$, thoriated $\mathrm{UBe}_{13}$ and compare them to earlier results of our group on $\mathrm{UPt}_{3}[1]$. For this purpose, we performed relaxation measurements of the remnant magnetization from a metastable configuration originating from the application of a magnetic field. In all three systems, we have discovered a new pinning mechanism which is very distinct from the standard pinning by defects. It manifests itself in a completely different vortex dynamics than the one observed in classical, or in high $-T_{C}$ superconductors. The novel pimning mechanism is so strong that no vortex creep is observed in a time scale of several hours. Its strength increases with decreasing temperature. This pinning mechanism is not material dependent, but rather intrinsic to the unconventional superconducting state of these systems.

Sigrist and Agterberg [2] interpreted the lack of vortex creep which we observe in these materials as being due to domain walls, separating different degenerate superconducting states. Such domain walls may form in superconductors with broken time reversal symmetry. A conventional vortex approaching such a domain wall can decay into vortices with fractional flux quanta. Since fractional vortices can only exist on the domain walls, and the sum of their line energies is smaller than that of one conventional vortex, the former remain strongly pinned in the domain wall. Due to vortex-vortex repulsion, domain walls occupied with pinned fractional vortices, represent efficient barriers for vortex motion and thus prevent flux flow.

In the case of $\mathrm{UPt}_{3}$ and $\mathrm{U}_{0.9725} \mathrm{Th}_{0.0275} \mathrm{Be}_{13}$, two consecutive phase transitions are known to occur of which the low-temperature one leads to a superconducting phase with 
broken time reversal symmetry [3-5]. In both systems, we observe a sharp drop of initial creep rates by more than three orders of magnitude to undetectabely low levels. This reduction of creep rates coincides exactly with the low-temperature transition. The novel pinning regime is only found in the low-temperature phase of $\mathrm{UPt}_{3}$ and $\mathrm{U}_{0.9725} \mathrm{Th}_{0.0275} \mathrm{Be}_{13}$, in the high-temperature phase rather large creep rates are observed, which increase with increasing temperature.

$\mathrm{In} \mathrm{Sr}_{2} \mathrm{RuO}_{4}$ time reversal symmetry breaking is reported to occur right below $T_{C}[6]$. However, we do not observe unconventional pinning immediately below the superconducting transition, but zero creep sets in only much below $T_{C}$. If the unconventional pinning mechanism described in this thesis is caused by domain walls carrying fractional vortices, as proposed by Sigrist and Agterberg [2], then one has to conclude that the domain walls in $\mathrm{Sr}_{2} \mathrm{RuO}_{4}$ cannot carry fractional vortices at all temperatures, but only at the lowest [7]. While in $\mathrm{U}_{0.9725} \mathrm{Th}_{0.0275} \mathrm{Be}_{13}$ and $\mathrm{UPt}_{3}$, the drop in creep rates at the lower superconducting transition temperature is very sudden and strong, in $\mathrm{Sr}_{2} \mathrm{RuO}_{4}$ it looks more like a crossover. Sigrist and Agterberg suggest that this crossover might be associated with a "transition" of domain wall states due to the multiband nature of the superconducting state in $\mathrm{Sr}_{2} \mathrm{RuO}_{4}[2]$. 


\section{Kurzfassung}

Im Rahmen dieser Dissertation wurde die Dynamik von Flusslinien in den unkonventionellen Supraleitern $\mathrm{Sr}_{2} \mathrm{RuO}_{4}$ und thoriertem $\mathrm{UBe}_{13}$ untersucht und mit vorangegangenen Ergebnissen unserer Gruppe an $\mathrm{UPt}_{3}[1]$ verglichen. Um das Flusskriechverhalten zu erforschen, wurde die Relaxation der remanenten Magnetisierung von einer metastabilen Konfiguration, die durch Anlegen eines Magnetfeldes hervorgerufen wurde, gemessen. In allen drei Systemen haben wir einen neuartigen Haftmechanismus gefunden, der sich wesentlich von dem Standard-Haften an Defekten unterscheidet. Dieser zeigt sich in einer völlig anderen Flussdynamik als diejenige welche in klassischen oder HochtemperaturSupraleitern vorgefunden wird. Der neuartige Haftmechanismus ist so stark, dass kein Flusskriechen in einem Zeitraum von mehreren Stunden beobachtet wird. Die Haftkraft nimmt mit sinkender Temperatur zu. Dieser Haftmechanismus ist nicht materialabhängig, sondern vielmehr dem unkonventionellen supraleitenden Zustand dieser Systeme inhärent.

Sigrist und Agterberg [2] haben die Unterdruickung von Flusskriechen, welches wir in diesen Materialien beobachten, der Existenz von Domänenwänden zugeschrieben, die verschiedene entartete supraleitende Zustände voneinander trennen. Diese Domänenwände können in Supraleitern mit gebrochener Zeitumkehrsymmetrie enstehen. Eine konventionelle Flusslinie (Vortex) die auf eine solche Domänenwand trifft kann in Vortizes mit nicht ganzzahligen Flussquanten zerfallen (fraktionierte Vortizes). Fraktionierte Vortizes existieren nur auf den Domänenwänden. Da die Summe ihrer Linienenergie kleiner ist als die von einem konventionellen Vortex, bleiben die fraktionierten Flusslinien in den Domänenwänden stecken. Wegen der gegenseitigen Abstossung der Vortizes, stellen Domänenwände die mit fraktionierten Flusslinien besetzt sind sehr starke Haftzentren dar, 
die wie "Einzäunungen" Vortizes in den Domänen umschliessen und damit die Bewegung der Fluslinien aus der Probe heraus unterbinden können.

In $\mathrm{UPt}_{3}$ und $\mathrm{U}_{0.9725} \mathrm{Th}_{0.0275} \mathrm{Be}_{13}$ gibt es zwei aufeinanderfolgende Phasenübergänge von welchen der Tieftemperatur-Übergang zu einem supraleitenden Zustand mit gebrochener Zeitumkehrsymmetrie führt [3-5]. In beiden Systemen beobachten wir exakt am Übergang zur Tieftemperaturphase eine aussergewähnlich starke und abrupte Abnahme der Anfangskriechraten über mehr als drei Grössenordnungen, bis zu einem undetektierbar kleinen Wert. Der neue Haftmechanismus wird nur in der Tieftemperaturphase von $\mathrm{UPt}_{3}$ und $\mathrm{U}_{0.9725} \mathrm{Th}_{0.0275} \mathrm{Be}_{13}$ aktiviert, in der Hochtemperaturphase werden endliche Kriechraten gemessen, die mit steigender Temperatur zunehmen.

In $\mathrm{Sr}_{2} \mathrm{RuO}_{4}$ wurde die Brechung der Zeitumkehrsymmetrie direkt unterhalb der kritischen Temperatur beobachtet [6]. In diesem Material jedoch, wurde der oben beschriebene Haftmechanismus nicht gleich unterhalb des supraleitenden Überganges gemessen, sondern er setzt erst bei viel tieferen Temperaturen ein. Falls dieser ungewöhnlich starke Haftmechanismus tatsächlich durch Domänenwände mit fraktionierten Vortizes hervorgerufen wird, wie Sigrist und Agterberg [2] vorschlagen, so muss man aus diesen Beobachtungen schliessen, dass die Domänenwände in $\mathrm{Sr}_{2} \mathrm{RuO}_{4}$ nicht bei allen Temperaturen fraktionierte Flusslinien enthalten können, sondern nur weit unterhalb der supraleitenden Übergangstemperatur [7]. Während in $\mathrm{U}_{0.9725} \mathrm{Th}_{0.0275} \mathrm{Be}_{13}$ und $\mathrm{UPt}_{3}$ der Abfall der Kriechraten an dem unterem Phasenibergang sehr abrupt und scharf ist, so gleicht er in $\mathrm{Sr}_{2} \mathrm{RuO}_{4}$ eher einem Crossover. Sigrist und Agterberg schlagen vor, dass dieser einer Art "Übergang" von Domänenwandzuständen zugeschrieben werden könnte, der von der Mehrbänder-Natur des supraleitenden Zustandes in $\mathrm{Sr}_{2} \mathrm{RuO}_{4}$ [2] herrührt. 